\title{
2019 status report: Drilling into seismogenic zones of M2.0-M5.5 earthquakes in South African gold mines (DSeis project)
}

\author{
H. Ogasawara ${ }^{1}$, B. Liebenberg'2, M. Rickenbacher ${ }^{3}$, M. Ziegler ${ }^{3}$, \\ van H. Esterhuizen ${ }^{2}$, T.C. Onstott ${ }^{4}$, R.J. Durrheim ${ }^{5}$, M.S.D. Manzi ${ }^{5}$, \\ S. Mngadi ${ }^{5}$, Y. Yabe ${ }^{6}$, H. Ogasawara' ${ }^{1}$, S. Kaneki ${ }^{7}$, E. Cason ${ }^{8}$, \\ J-G. Vermeuren ${ }^{8}$, E. van Heerden ${ }^{9}$, T. Wiersberg' ${ }^{10}$, M. Zimmer ${ }^{10}$, \\ C. Kujawa10, R. Conze10, G. van Aswegen ${ }^{11}$, N. Wechsler12, \\ A.K. Ward13, S. Enslin' ${ }^{5}$, S. Tau' ${ }^{5}$, M.S. Bucibo'14, \\ and the DSeis Team. \\ ${ }^{1}$ Ritsumeikan University, Japan \\ ${ }^{2}$ Moab Khotsong mine, South Africa \\ ${ }^{3}$ ETH, Zurich, Switzerland \\ 4Princeton University, USA \\ 5University of the Witwatersrand, South Africa \\ ${ }^{6}$ Tohoku University, Japan \\ 7Osaka University, Japan \\ ${ }^{8}$ Free State University, South Africa \\ 9i Water Solutions, South Africa \\ ${ }^{10}$ ICDP, GFZ, Germany \\ 11Institute of Mine Seismology Ltd, South Africa \\ ${ }^{12}$ Tel Aviv University, Israel \\ 13Seismogen CC, South Africa \\ ${ }^{14}$ Council for Geoscience, South Africa
}

\begin{abstract}
In 2014, a M5.5 earthquake ruptured the range of depths between $3.5 \mathrm{~km}$ and $7 \mathrm{~km}$ near Orkney, South Africa. The main and aftershocks were very well monitored in the nearfield by dense, surface, strong motion meters and a dense underground seismic network in the deep gold mines. The mechanism of this M5.5 earthquake was left-lateral strike-slip faulting, differing from typical mining-induced earthquakes with normalfaulting mechanisms on the mining horizons shallower than $3.5 \mathrm{~km}$ depth. To understand why such an unusual event took place, the aftershock zone was probed by full-core NQ drilling during 2017-2018, with a total length of about $1.6 \mathrm{~km}$, followed by in-hole geophysical logging, core logging, core testing, and monitoring in the drilled holes. These holes also presented a rare opportunity to investigate deep life. In addition, seismogenic zones of M2-M3 earthquakes were probed on mine horizons that were also very well monitored by acoustic emission networks. This paper reviews the early results of the project.
\end{abstract}




\section{INTRODUCTION}

A better understanding of the seismogenic processes of earthquakes is critical for deep mining and highly stressed ground, as well as disaster mitigation in countries prone to natural earthquakes. Built on the outcomes of the Japanese - South African seismological collaboration since 1992, Japanese and South African researchers and six deep South African gold mines collaborated during 2010-2015 in a multidisciplinary study of the response of the rock mass to mining and mining-induced earthquakes particularly the 2014 M5.5 Orkney earthquake below the mining horizons at the Moab Khotsong mine. See Figure 1, Ogasawara et al, 2014a and Durrheim, 2015.

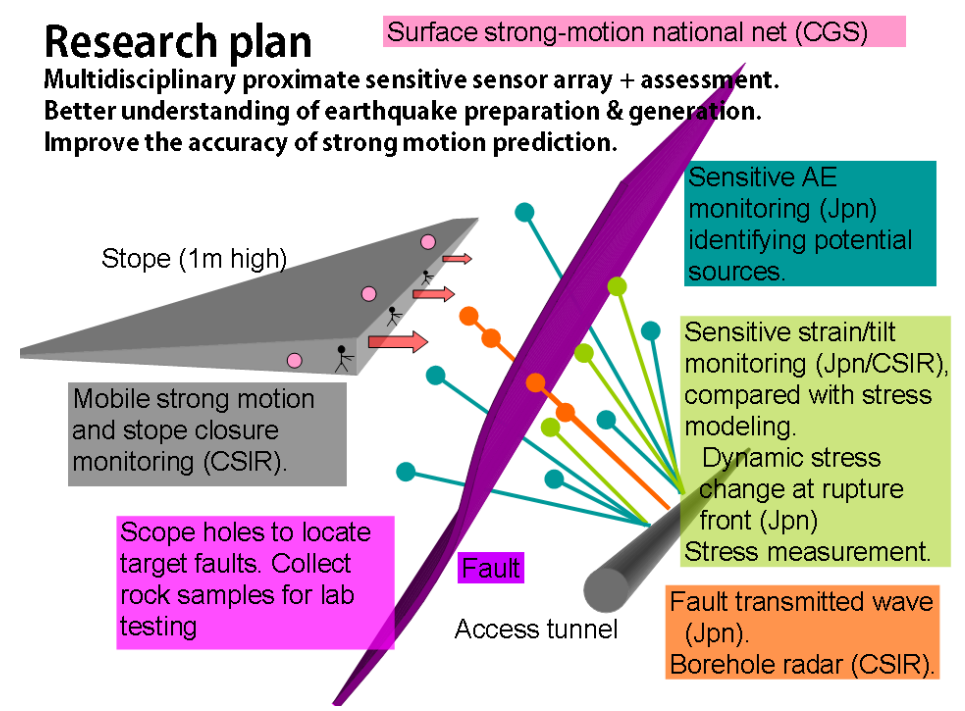

Figure 1. Schematic illustration of the SATREPS research plan. Jpn: Japanese researchers, CSIR: Council for Scientific and Industrial Research, CGS: Council for Geoscience Ogasawara et al (2014a)

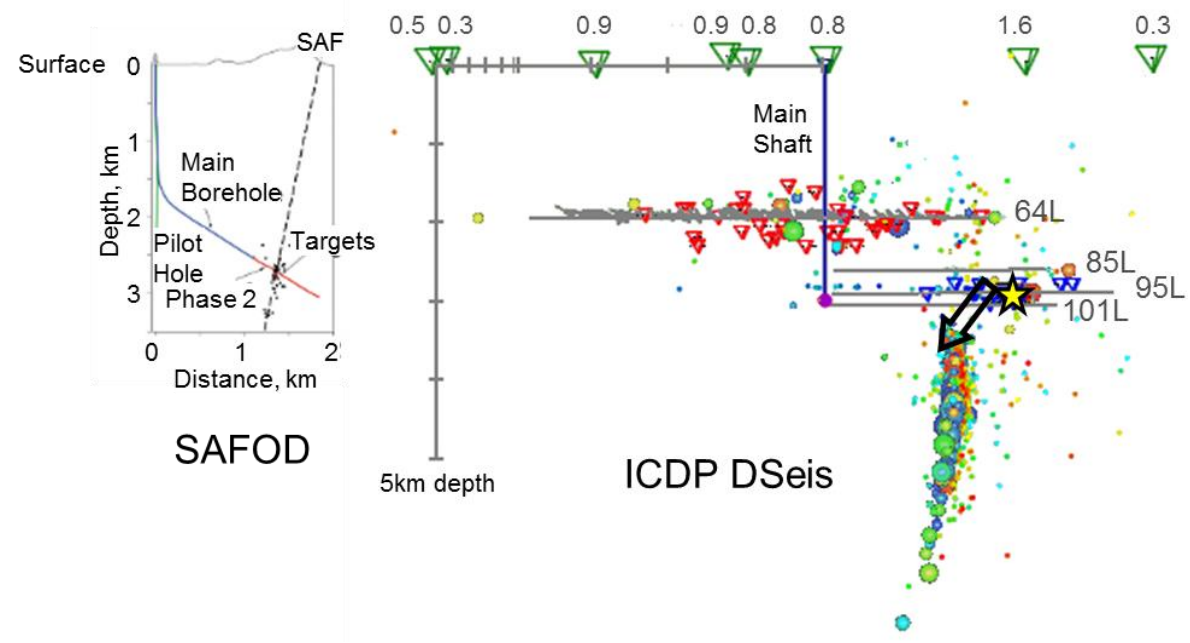

Figure 2. Comparison of two deep scientific drilling projects. Left: San Andreas Fault Observatory at Depth (SAFOD; modified after Hickman et al(2007). Right: DSeis on the same scale, Ogasawara et al (2017). Spheres: aftershocks of the 2014 Orkney M5.5 earthquake and earthquakes induced on mining horizons at the Moab Khotsong mine (data courtesy of AngloGold Ashanti Ltd). Surface larger triangles: Council for Geoscience National Seismograph Network strong motion meters with PPA, G. Smaller triangles at mining depths: in-mine network of accelerometers and $4.5 \mathrm{~Hz}$ geophones. Holes were drilled from mining level $95 \mathrm{~L}, 2.9 \mathrm{~km}$ from surface with a rig used for underground routine drilling of geological exploration. Star: A site where normal-faulting stress regime was measured on mining level 98 L, Ogasawara et al (2012) 
The research sought to determine how ruptures $(\mathrm{Mw}>-4)$ evolve in space and time ahead of mining faces at the Cooke 4 mine and a highly stressed dyke at the Mponeng mine (Nakatani et al (2008), Naoi et al (2011, 2014, 2015abc) and Yabe et al (2015), in Figure 1).

Also investigated, was the adaptation and implementation of new core-stress measurement techniques that are easier to apply. One of these is the down-sized compact conical-ended borehole overcoring (CCBO) technique, Sugawara and Obara (1999), which enhances the calibration of stress modelling Ogasawara et al (2012, 2014b); and Hofmann et al (2013), and improves the understanding of stress states in earthquake-prone ground. As Yabe et al (2019) detail, additional core-stress-measurements deformation rate analysis (DRA; Yamamoto, 2009) and diametrical core deformation analysis (DCDA; Funato and Ito, 2017) were carried out on the dyke core samples, resulting in much better constraints on the stress state in the seismogenic zone. The CCBO stress-measurement technique proved the existence of a normal-faulting stress regime at mining horizons. See star in Figure 2, Ogasawara et al (2012).

Enhancement of the Council for Geoscience (CGS) National Seismograph Network with the deployment of surface strong motion meters in gold mining districts, was included in the study. This national network was enhanced with 15 strong motion meters within a radius of $25 \mathrm{~km}$ in the Klerksdorp district, which could record the Orkney M5.5 earthquake on 5 August 2014, and the aftershocks, Midzi et al (2015). Together with the strong motion data, 46 in-mine seismic sensors, mainly geophones, installed at depths of $2 \mathrm{~km}-3 \mathrm{~km}$ at distances of $3 \mathrm{~km}-8 \mathrm{~km}$ from the M5.5 hypocentre, allowed detailed investigation of the event (Moyer et al (2017), Imanishi et al (2017), Mori et al (2018) and Manzunzu et al (2017), Figure 2). This M5.5 earthquake was atypical because the mechanism was strike-slip faulting instead of typical normal-faulting, and it took place at a depth significantly greater than the mining horizons in a normal-faulting stress regime. No significant geological structures other than a dyke only $2 \mathrm{~m}-3 \mathrm{~m}$ thick was mapped on the mining horizons above the nearly vertical planar distribution of the aftershocks.

Seismogenic zones with different sizes provide unique targets for scientific drilling to better understand (1) what controls seismogenic processes, (2) how they scale, and (3) how faults evolve. In August 2016, the International Continental Scientific Drilling Program (ICDP) approved the project Drilling into M2.0-M5.5 earthquakes in South African gold mines (DSeis). The drilling targets originally included the seismogenic zones at the Moab Khotsong mine and the Cooke 4 mine, as well as a seismogenic zone at a dyke at the Savuka mine that was responsible for a M3.5 earthquake, van Aswegen (2017). The DSeis drilling commenced in June 2017,Voosen (2017) and was completed in June 2018. Because of mine closure in 2016 at the Cooke 4 mine, only limited ICDP DSeis drilling could be carried out at the mine. However, ruptures were recovered with a triple-tube, Wechsler et al (2018) and Mngadi et al (2019). The Savuka mine was closed in 2017 resulting in the cancellation of the ICDP DSeis drilling. However, a pilot project supported by the Savuka mine with significant outcomes detailed by Yabe et al (2019; this conference), was completed.

In the following sections, the drilling into the M5.5 seismogenic zone below the Moab Khotsong mine is described in detail.

\section{THE 2014 ORKNEY M5.5 EARTHQUAKE}

The 2014 M5.5 Orkney earthquake took place in metamorphosed sedimentary and volcanic rocks in the $2.9 \mathrm{Ga}$ West Rand Group, which is overlain by the 2.8Ga - 2.9 Ga Central Rand Group that hosts the Vaal Reef ore body, Catuneanu and Biddulph (2001). The dense in-mine geophone network, deployed to the south of the hypocentre of the Orkney M5.5 earthquake, delineated a nearly vertically-dipping planar distribution of aftershocks (See Figure 2). The CGS surface strong motion network covers the areas both to the south and north of the epicentre, allowing the locating of aftershocks to the north of the epicentre and investigation the rupture process of the M5.5 mainshock, Ellsworth et al (2017), 
Moyer et al (2017) and Mori et al (2018). The deepest mining horizons are $3 \mathrm{~km}$ below surface, and the upper fringe of the aftershock zone several hundreds of metres below them, which is within the range of the hydraulic drilling rigs that are used for routine mine exploration and cover drilling (pilot drilling in advance of tunnel development).

\section{ICDP DSEIS DRILLING AND ASSOCIATED INVESTIGATION}

A location was found in the local-tension (T) quadrant of the M5.5 strike slip fault, which was suitable for drilling into the seismogenic zone sub-parallel to the expected near-horizontal direction of the maximum principal stress to minimize borehole breakout or core discing. A chamber of $6 \mathrm{~m}$ wide $\times 6$ $\mathrm{m}$ wide $\times 6 \mathrm{~m}$ high (the largest height the mine safety regulation allows) was constructed by blasting the rock mass. The drilling plunged at $35^{\circ}-45^{\circ}$ downward to intersect beddings at higher angles. NQ diameter drilling was selected, i.e., the minimum diameter that allows borehole geophysical logging. A $3 \mathrm{~m}$ long double-tube core barrel was used for full-core recovery for most of the drilling.

Hole A drilling started in June 2017. Hole A deviated from its planned trajectory to run eventually subparallel and roughly $100 \mathrm{~m}$ from the aftershock zone, traversing the periphery of the M5.5 aftershock zone for a distance of several hundred metres. As Hole A did not intersect the M5.5 fault, drilling was terminated at $817 \mathrm{~m}$ drilled length (See Figure 3). However, Hole A was stable enough to conduct borehole logging throughout the hole. Core recovery was almost $100 \%$ from metasiltstones and quartzites of the Upper Roodepoort Formation down to quartzite of the Babrosco Formation of the West Rand Group. Six mafic intrusives (sills) and metabasalt of the Crown Formation were also intersected, Ziegler et al (2018). As Yabe et al (2019, this conference) report, stress concentration was found at the intrusive at a distance of about $440 \mathrm{~m}$ along Hole A from the borehole collar. Another stress concentration was found at a depth of the upper fringe of the aftershock zone.
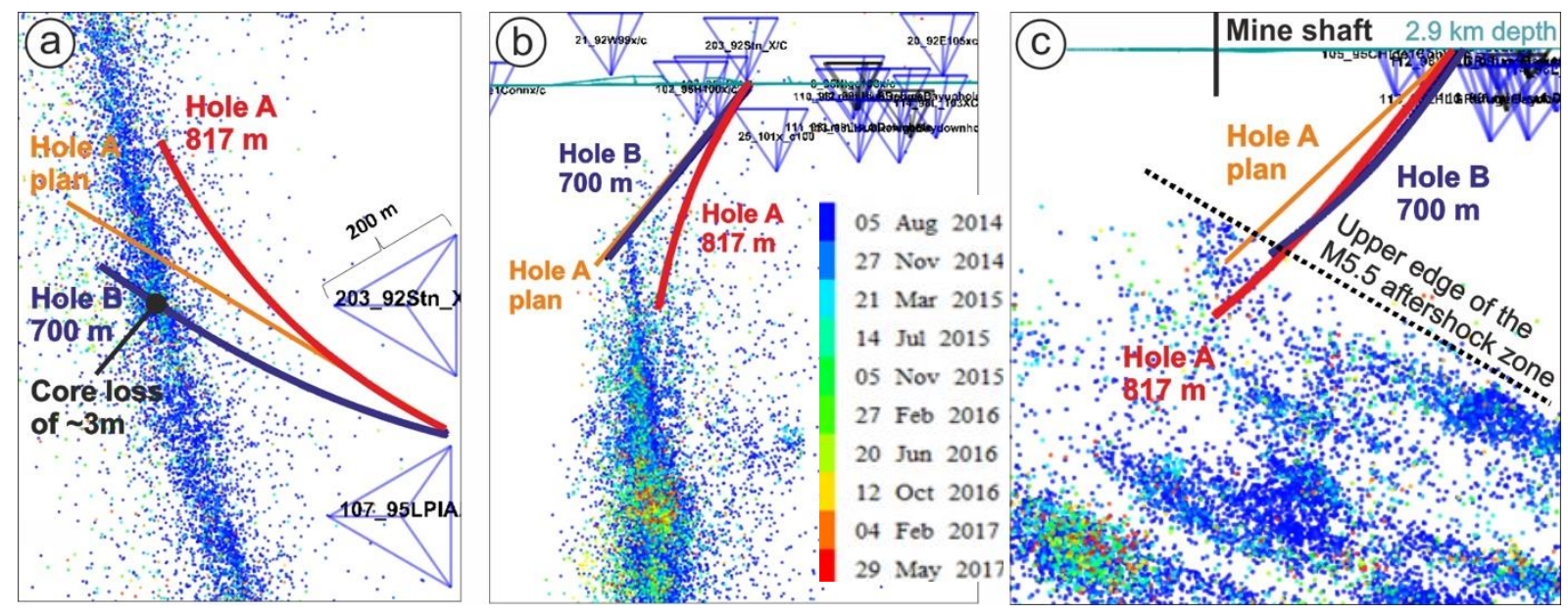

Figure 3. Configuration of the aftershocks of the M5.5 earthquake, Holes A and B, in-mine seismometers, and haulage horizontal tunnels on 95 level. (a): plan view. (b) and (c): vertical sectional views in parallel to and normal to the planar after-shock distribution, respectively -modified after Ziegler et al( 2018). Each seismometer is centred on each triangle with $200 \mathrm{~m}$ side length. Hole A deflected too much to intersect the aftershock zone, while, Hole B intersected a fracture zone with $\sim 3$ core loss

The drilling rig was swung by $15^{\circ}$ to drill Hole B (See Figure 3). Hole B intersected the same formations as Hole A until we intersected an intrusive (Not seen in Hole A), followed by an approximately $3 \mathrm{~m}$ long core-loss zone in Hole B, beginning at $612 \mathrm{~m}$ drilled length from the borehole collar. Drillers reported water loss and a methane pocket. Drilling was stopped when relatively intact quartzite was intersected in the Babrosco Formation at $700 \mathrm{~m}$. As the hole was unstable at the intersection of the coreloss zone, borehole geophysical logging could not be conducted at and beyond the fault intersection. 
Rickenbacher (2018) and Ziegler et al (2018) compiled drilling information, borehole logs and core geology, and measured the mechanical properties of representative metasedimentary and intrusive rocks for Hole A and Hole B. An intrusive was found that was different from the others near the coreloss zone. Around the core loss zone, Kaneki et al (2018) found talc and biotite, which are known to be materials with low friction and often characterise seismogenic processes, such as slip-weakening or slipstrengthening, Moore and Lockner (2004), and Moore and Michael (2007). Amorphous sub-micron material was also found, suggesting the rupturing is not older than several hundreds of years, Hirono et al (2016). It is believed the core-loss zone corresponds to the pre-existing geological structure that was responsible for the M5.5 earthquake.

In order to double-check and recover more fault material, a branch hole (Hole C) was drilled from $545 \mathrm{~m}$ distance from the collar of Hole B with a deviation of about $2^{\circ}-3^{\circ}$ from Hole B. At the fault intersection, a $1.5 \mathrm{~m}$ long triple-tube core-barrel was used to give a much better recovery of the fault zone. Hole $\mathrm{C}$ drilling was terminated when the Babrosco quartzite was reached.

The entire core was transported from the mine to the Mandela Mining Precinct, CSIR, Johannesburg, with sufficient space to lay out all the core for systematic study. The lithology sequence was found to be consistent between Hole A, Hole B, and Hole C. The team from the University of the Witwatersrand optically scanned the cylindrical surface of the entire core to provide unrolled $360^{\circ}$ images with a DMT CoreScan3 optical scanner provided by ICDP.

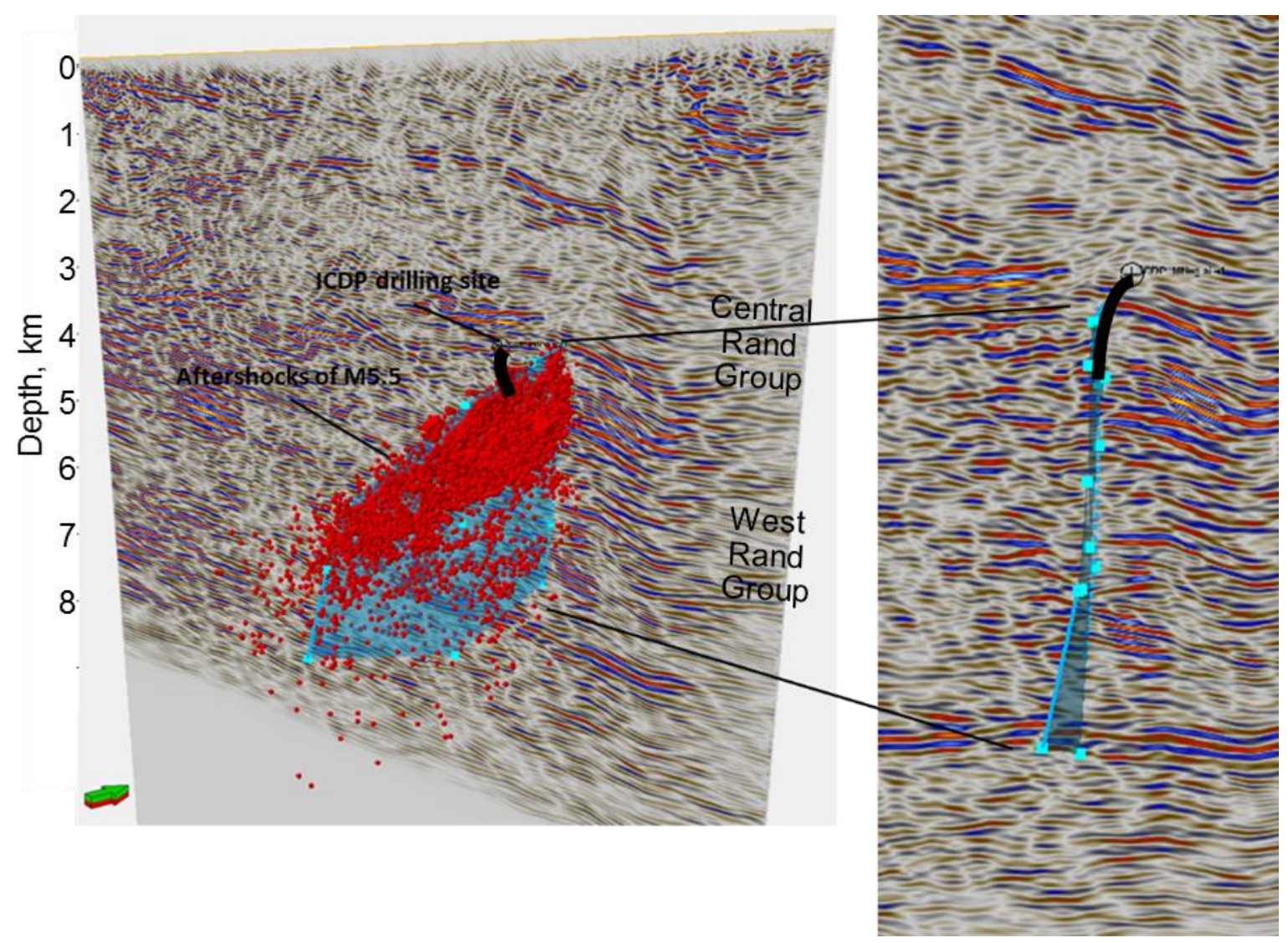

Figure 4. A 2D seismic reflection image in a vertical section with the M5.5 aftershocks and DSeis Hole A (a thick black lines). Data after Ogasawara et al (2017). It is notable that the M 5.5 aftershock zone encompasses almost the entire thickness of the West Rand Group characterized by multiple reflectors 


\section{WATER AND GAS MONITORING}

The geomicrobiology team headed by T.C. Onstott, one of the co-authors, installed a packer with downhole pressure and temperature transducers at a fissure zone in a mafic intrusive at $420 \mathrm{~m}$ depth in Hole A, and measured the water pressure at approximately about $10 \mathrm{MPa}$, Rusley et al (2018). The sampled water was hypersaline brine, quite different from the water in the near-surface dolomite formation sampled at $1200 \mathrm{~m}$ depth in the shaft.

The geomicrobiologists also searched for hypersaline brine at the other localities on mining horizons, finding brine at a geology hole drilled from $101 \mathrm{~L}$ and on other haulages. The team from the German Research Centre for Geosciences (GFZ Potsdam) started gas monitoring in Hole A and Hole B, Wiersberg et al (2019).

\section{LEGACY SEISMIC REFLECTION EXPLORATION DATA}

Two-dimensional seismic reflection data that AngloGold Ashanti acquired in 1992, was re-processed and interpreted, Ogasawara et al (2017). It was confirmed that the 2014 Orkney earthquake ruptured the entire West Rand Group on a sub-vertical structure that was potentially responsible for the M5.5 earthquake (See Figure 4). As the area of interest is geologically too complex to be delineated by twodimensional reflection data, AngloGold Ashanti acquired 3D data in 1996, which is being re-processed and re-interpreted, Linzer et al (2018). Further research is expected to reveal more detail of the responsible structure. There will also be an attempt to delineate the extent of the intrusives with high stress and the intrusives associated with saline water. The intrusives will be compared with the M5.5 aftershock distribution.

\section{SUMMARIES}

The 2014-2019 ICDP science plan states: "reaching the depths of the seismogenic zone where earthquakes nucleate has always been a challenge for fault-zone drilling projects", Mori and Ellsworth (2013). Brodsky et al (2009), stated that, "the reliable measurement of the magnitude and orientation of stress at depth is a significant challenge". However, drilling in deep South African gold mines enabled the researchers to probe the normal-faulting stress regime near the mining horizon, the zone of strikeslip-faulting aftershocks produce by a M5.5 earthquake, and a seismic gap in-between the normal and strike-slip stress regimes by means of full-core drilling followed by geophysical logging and core stress measurements (Yabe et al, this conference). This study has also allowed geomicrobiologists to start investigation of the saline water and gas that they targeted. Multidisciplinary investigation is ongoing for additional integrated outcomes.

\section{ACKNOWLEDGEMENT}

This scientific drilling and associated study is built on the outcomes of the projects in the JST-JICA SATREPS programme and JSPS grant-in-aid, and is supported by the International Continental Scientific Drilling Program (ICDP), JSPS Core-to-Core Program; JSPS-NRF Bilateral Research Program, grant-in-aid for scientific research(S); grant-in-aid for scientific research on innovative areas; Bilateral Joint Research Projects and the Ministry of Education, Culture, Sports, Science and Technology (MEXT) of Japan, under its Earthquake and Volcano Hazards Observation and Research Program; DST and NRF South Africa through the South African Research Chair Initiative (SARChI) and the Centre of Excellence in Mineral and Energy Resource Analysis (CIMERA), ETH Zurich; US NSF; German DFG; Ritsumeikan University and Tohoku University. We also thank two anonymous reviewers for their valuable comments.

We thank AngloGold Ashanti Ltd, Harmony Gold Ltd, Sibanye Stillwater Ltd, Lesedi Drilling Ltd, Digital Surveying Ltd, OHMS Ltd, Seismogen CC, and 3D Geoscience. 


\section{REFERENCES}

Brodsky, E.E., Ma, K.-F., Mori, J., Saffer, D.M. and the participants of the ICDP/SCEC International Workshop (2009). Rapid response fault drilling: past, present, and future. Scientific Drilling, 8, 6674 .

Catuneanu, O. and Biddulph, M.N. (2001). Sequence stratigraphy of the Vaal Reef facies associations in the Witwatersrand foredeep, South Africa. Sedimentary Geology, 141-142, 113-130.

Durrheim, R.J. (2015). Geophysical laboratories in deep gold mines: earthquakes, neutrinos, extremophiles and the origin of the Earth's magnetic field. The History of Geophysics in Southern Africa. J.H. de Beer (ed.). SUN MeDIA, Stellenbosch, pp. 116-138.

Ellsworth, W., Boettcher, M. and Ogasawara, H. (2017). A Test Case for the Source Inversion Validation: The 2014 ML 5.5 Orkney, South Africa Earthquake. Southern California Earthquake Center 2017 Annual Meeting, FARM, Poster199, 10-13 September 2017

Funato, A. and Ito, T. (2017). A new method of diametrical core deformation analysis for in-situ stress measurements, Int. J. Rock Mech. Min. Sci., 91, 112-118, doi: 10.1016/j.ijrmms.2016.11.002.

Hickman, S., Zoback, M., Ellsworth, W., Boness, N., Malin, P., Roecker, S. and Thurber, C. (2007). Structure and properties of the San Andreas Fault in central California recent results from the SAFOD experiment. Scientific Drilling, Special Issue 1, 29-32.

Hirono, T., Asayama, S., Kaneki, S. and Ito, A. (2016). Preservation of amorphous ultrafine material: A proposed proxy for slip during recent earthquakes on active faults. Scientific Reports, 6, 36536.

Hofmann, G., Scheepers, L. and Ogasawara, H. (2013). Loading conditions of geological faults in deep level tabular mines. Proceedings of the 6th Int. Symp. on In-Situ Rock Stress (RS2013), Sendai, Japan.

Imanishi, K., Ogasawara, H., Yabe, Y., Horiuchi, S., Okubo, M. and Murakami, O. (2017). Source parameters of the 2014 M5.5 Orkney earthquake sequence, South Africa, by using near-field underground seismic arrays in gold mines. Abstracts IASPEI 2017 Kobe, S02-1-03.

Kaneki, S., Yokoyama, Y., Hirono, T., Yabe, Y. and Ogasawara, H. (2018). Mineralogical characteristics of fault rocks recovered from aftershock zone of the M5.5 Orkney earthquake in South Africa (ICDP DSeis project). Abstracts Japan Seismol. Soc. Fall Meeting, S0-06.

Linzer, L., Manzi, M. and ICDP DSeis team (2018). Interpretation of the merged 3D seismic volume covering the seismogenic zone of M5.5 Orkney earthquake, South Africa, Abstract Jpn. Seismol. Soc. Fall Meeting S08-05, Koriyama, 10 October 2018.

Manzunzu, B., Midzi, V., Mangongolo, A. and Essrich, F. (2017). The aftershock sequence of the 5 August 2014 Orkney earthquake (ML 5.5), South Africa. J. Seismol. doi: 10.1007/s10950-017-9667z.

Midzi, V., Zulu, B., Manzunzu, B., Mulabisana, T., Pule, T., Myendeki, S. and Gubela W. (2015). Macroseismic survey of the ML5.5, 2014 Orkney earthquake, J. Seismol, 19: 741-751. doi:10.1007/s10950-015-9491-2.

Mngadi, S.B., Durrheim, R.J., Manzi, M.S.D., Ogasawara, H., Yabe, Y., Yilmaz, H., Wechsler, N., Van Aswegen, G., Roberts, D., Ward, A.K., Naoi, M., Moriya, H., Ishida, A., SATREPS team and ICDP DSeis team. (2019). Integration of underground mapping, petrology, and high-resolution microseismicity analysis to characterise weak geotechnical zones in deep South African gold mines. International Journal of Rock Mechanics and Mining Sciences. 114, 79-91. https://doi.org/10.1016/j.ijrmms.2018.10.003.

Moore, D.E. and Lockner, D.A. (2004). Crystallographic controls on the frictional behavior of dry and water-saturated sheet-structure minerals. J. Geophys. Res., 109, B03401, doi:10.1029/2003JB002582 
Moore, D.E. and Michael J.R. (2007). Talc-bearing serpentinite and the creeping section of the San Andreas fault. Nature, 446:16, 795-797. doi:10.1038/nature06064.

Mori, J. and Ellsworth, W. (2013). Active fault and earthquakes. Unravelling the Workings of Planet Earth - Science Plan for 2014-2019, pp. 24-31. http://www.icdp-online.org/fileadmin/icdp/media/ Science_Conference/ICDP_SciencePlan2014_2019.pdf

Mori, J.J., Yasutomi, T. and Ogasawara, H. (2018). Close Observations of the Rupture for the M5.5 Orkney, South Africa Earthquake. Tuesday, 11 December 2018. Abstract AGU Fall Meeting. S21C0438 .

Moyer, P.A., Boettcher, M.S., Ellsworth, W.L., Ogasawara, H., Cichowicz, A., Birch, D. and van Aswegen, G. (2017), Call for Models - A Test Case for the Source Inversion Validation: The 2014 ML 5.5 Orkney, South Africa, Earthquake, Seismol. Res. Lett., 88(4), doi: 10.1785/0220160218

Nakatani, M., Yabe, Y., Philipp, J., Morema, G., Stanchits, S., Dresen, G. and JAGUARS Group (2008). Acoustic emission measurements in a deep gold mine in South Africa-Project overview and some typical waveforms, Seismol. Res. Lett., 79, 311.

Naoi, M., Nakatani, M., Yabe, Y., Kwiatek, G., Igarashi, T. and Plenkers, K. (2011). Twenty thousand aftershocks of a very small (M2) earthquake and their relation to the mainshock rupture and geological structures. Bull. Seis-mol. Soc. Amer. 101, 2399-2407, doi: 10.1785/0120100346.

Naoi, M., Nakatani, M., Horiuchi, S., Yabe, Y., Philipp, J., Kgarume, T., Morema, G., Khambule, S., Masakale, T., Ribeiro, L., Miyakawa, K., Watanabe, A., Otsuki, K., Moriya, H., Murakami, O., Kawakata, H., Yoshimitsu, N., Ward, A., Durrheim, R. and Ogasawara, H. (2014). Frequencymagnitude distribution of $-3.7<\mathrm{Mw}<1$ mining-induced earthquakes around a mining front and b value invariance with post-blast time. Pure and Applied Geophysics, 171, 2665-2684. doi 10.1007/s00024-013-0721-7.

Naoi, M., Nakatani, M., Otsuki, K., Yabe, Y., Kgarume, T., Murakami, O., Masakale, T., Ribeiro, L., Ward, A., Moriya, H., Kawakata, H., Durrheim, R. and Ogasawara, H. (2015a). Steady activity of microfractures on geological faults loaded by mining stress, Tectonophysics, 649, 100-114. doi: 10.1016/j.tecto.2015.02.025.

Naoi, M., Nakatani, M., Kgarume, T., Khambule, S., Masakale, T., Ribeiro, L., Philipp, J., Horiuchi, S., Otsuki, K., Miyakawa, K., Watanabe, A., Moriya, H., Murakami, O., Yabe, Y., Kawakata, H., Yoshimitsu, N., Ward, A., Durrheim, R. and Ogasawara, H. (2015b). Quasi-static slip patch growth to $20 \mathrm{~m}$ on a geological fault inferred from acoustic emissions in a South African gold mine, Journal of Geophysical Research Solid Earth, 120, 1692-1707.

Naoi, M., Nakatani, M., Igarashi, T., Otsuki, K., Yabe, Y., Kgarume, T., Murakami, O., Masakale, T., Ribeiro, L., Ward, A., Moriya, H., Kawakata, H., Nakao, S., Durrheim, R. and Ogasawara, H. (2015c). Unexpectedly frequent occurrence of very small repeating earthquakes $(-5.1 \leq \mathrm{MW} \leq-$ 3.6) in a South African gold mine: implications for monitoring intraplate faults, Journal of Geophysical Research, 120, 8478-8493.

Ogasawara, H., Kato, H., Hofmann, G. and De Bruin, P. (2012). Trial of the BX conical-ended borehole overcoring stress measurement technique, J. SAIMM, 102, 749-754. 
Ogasawara, H., Nakatani, M., Durrheim, R.J., Naoi, M., Yabe, Y., Moriya, H., Hofmann, G.F., Stander, C., Roberts, D.P., De Bruin, P., Oelofse, J., Kato, H., Cichowicz, A., Birch, D., Ngobeni, D., Milev, A., Kgarume, T., Satoh, T., Horiuchi, S., Kawakata, H., Murakami, O., Yoshimitsu, N., Ward, A.K., Wienand, J., Lenegan, P., Yilmaz, H., Mngadi, S., Piper, P.S., Clements, T.N., Nakao, S., Okubo, M., Ishii, H. and Visser, A.V. (2014a). Observational studies of the rock mass response to mining in highly-stressed gold mines in South Africa. Proceedings of the Seventh International Congress on Deep and High Stress Mining, Hudyma, M. and Potvin, Y. (eds), Australian Centre for Geomechanics, Perth. pp. 123-137.

Ogasawara, H., Kato, H., Hofmann, G., Roberts, D., Piper, P., Clements, T., Ward, A.K., Yabe Y., Yilmaz, H. and Durrheim, R.J. (2014b). BX CCBO in-situ stress measurements at earthquake prone areas in South African gold mines- a summary of mini-workshop on 13 Feb 2014. Proceeding of the American Rock Mechanics Association annual symposium, ARMA2014, Minneapolis, CD-ROM, paper number 14-7438.

Ogasawara, H.Y., Manzi, M., Durrheim, R. and Ogasawara, H. (2017). Calibration of the seismic velocity structure and understanding of the fault formation in the environs of the Orkney M5.5 earthquake, South Africa. Abstracts AGU 2017 Fall Meeting, \#S51A-0570.

Rickenbacher, M. (2018). Geological and geotechnical rock mass model from two deep DSeis boreholes drilled at Moab Khotsong. MSc thesis. ETH Zurich, Switzerland.

Rusley, C., Onstott, T.C., Liang, R. Higgins, J.A., Slater, N.W., Ogasawara, H., Cason, E.D., Sherwood, B., Lollar, B., Wiersberg, T., Zimmer, M., van Heerden, E., Kieft, T.L., Freese, B., Liebenberg, B. and Esterhuizen, V.H. (2018). Exploring the limits of life in a South African deep subsurface brine. Abstract B23E-2552 AGU 2018 Fall meeting, Washington DC, 11 December 2018.

Sugawara K. and Obara Y. (1999). Draft ISRM suggested method for in situ stress measurement using the compact conical-ended borehole overcoring (CCBO) technique. International Journal of Rock Mechanics and Mining Sciences, 36, 307-322.

Van Aswegen, G. (2017). Keynote Lecture: Seismic sources and rockburst damage in South Africa and Chile. Proceedings of the 9th International Symposium on Rockbursts and Seismicity in Mines (RaSiM9). Vallejos, J.A (ed.). Feyser Impresores. Santiago. pp. 72-87.

Voosen, P. (2017). Deep in a South African gold mine, scientists drill for the heart of an earthquake. Science. doi:10.1126/science. aan6905. 31 May 2017.

Wechsler, N., Van Aswegen, G., Yabe, Y., Mngadi, S., Kamhaji, L., Ward, A., Morema, S., Durrheim, R., Ogasawara, H. and ICDP DSeis team. (2018). Recovery of ruptures from seismogenic zone at Cooke 4 mine (DSeis - ICDP scientific drilling project in the South-African gold mines). Abstract EGU 2018-9721, Vienna, 12 April 2018.

Wiersberg, T., Zimmer, M., Kujawa, C., Liebenberg, B., Ogasawara, H., Onstott, T.C., Cason, E., Vermeulen, Jan-G and van Heerden, E. (2019). Investigations on fault zone gases in South African gold mines. Abstract EGU2019-5670, SSP1.2/CL1.32/EMRP3.11/GD2.9/GMPV1.7/NH5.12/ TS1.4, 7-12 April 2019, Vienna.

Yabe, Y., Nakatani, M., Naoi, M., Philipp, J., Janssen, C., Watanabe, T., Katsura, T., Kawakata, H., Georg, D. and Ogasawara, H. (2015). Nucleation process of an M2 earthquake in a deep gold mine in South Africa inferred from on-fault foreshock activity, Journal of Geophysical Research, 120, 55744495. 
Yabe, Y., Abe, S., Ito, T., Ishida, A., Sugimura, K., Kanematsu, M., Higashi, M., Tadokoro, R., Ogasawara, H., Funato, A., Kato, H., Watson, B., Mngadi, S., Durrheim, R., Hofmann, G. and Scheepers, L. (2019). In-situ stress around earthquake source faults in and beneath South African deep gold mines. Proceedings of International Conference on Deep Mining 2019. This volume, SAIMM, Johannesburg.

Yamamoto, K. (2009). A theory of rock core-based methods for in-situ stress measurement, Earth Planets Space, 61, 1143-1161.

Ziegler, M., Rickenbacher, M., Berset, N., Liebenberg, B., Ishida, A., Sugimura, K., Noda, T.,

Ogasawara, H., Mngadi, S., Durrheim, R., Ito, T., Funato, A. and the ICDP DSeis team. (2018). Core and borehole logging and stress measurements of a $817 \mathrm{~m}$ long borehole drilled from 2.9 $\mathrm{km}$ depth toward the Moab Khotsong 2014 M5.5 aftershock zone (ICDP DSeis project in South Africa). Abstract EGU2018-10377, Vienna, 12 April 2018.

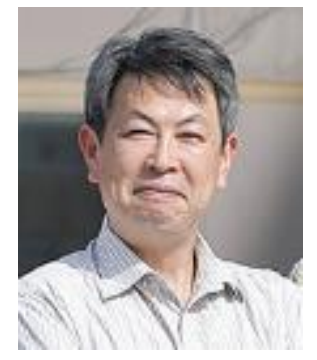

\section{Hiroshi Ogasawara}

Kyoto University

Professor Hiroshi Ogasawara (PhD), has carried out seismological research in South African gold mines since 1992, and is now PI of the ICDP project Drilling into seismogenic zones of M2.0 - M5.5 earthquakes from deep South African gold mines (DSeis, 2016-present). He was co-leader of the Japanese-South African collaborative project Observational studies in South African mines to mitigate seismic risks (2010-2015). 